\title{
PENGEMBANGAN BAHAN AJAR MATERI ENTREPRENURERSHIP BERBASIS INTERNET MARKETING
}

\author{
Alif Ringga Persada, S.Si., M.Pd. \\ kotaksurat_ringga@yahoo.co.id \\ Dosen Tadris Matematika IAIN Syekh Nurjati Cirebon
}

\begin{abstract}
Student skill of concerning entrepreneurship still need the existence of improvement in order to become better again. Technological growth make the disrupted in running kewirausahaan so that need the skill entrepreneurship base on the internet marketing. this Research target is make the teaching material the entrepreneurship base on the internet marketing which valid. Research method used by is research and development with the model of development ADDIE covering step Analysis, Design, Development, Impelementation And Evaluation. Result of research and development is teaching material the entrepreneurship base on the internet marketing which have valid by expert. Response Student to teaching material the entrepreneurship with the mean $66 \%$. mean Pretes of equal to 58,55 and postes 83,55. Pursuant to test of paired sampel $t$-test known by the existence of difference of result of learning which signifikan to teaching material the entrepreneurship base on the internet marketing.
\end{abstract}

Keyword: Material Learning, Entrepreneurship, Internet Marketing

\section{PENDAHULUAN}

Indonesia merupakan negara kepulaian yang tidak sedikit jumlah penduduknya. Di Indonesia sediri saat ini tercatat ada 255, 993, 674 jumlah populasi, jumlah populasi tersebut tidak bisa dibilang sedikit. Banyaknya populasi ini membuat persaingan dalam dunia kerjapun menjadi sangat ketat. Sejalan dengan tingginya jumlah populasi di Indonesia, total penduduk yang mengalami pengangguran atau tidak memiliki pekerjaan tetap di Indonesia juga tinggi. Hal ini karena kurangnya persiapan lulusan-lulusan instansi pendidikan terhadap kehidupan kerja yang sesungguhnya. Banyak lulusan-lulusan dengan nilai baik namun belum siap terhadap dunia kerja yang mengakibatkan merasa jika penddikan yang mereka tempuh tidak sama dengan yang mereka butuhkan dalam dunia kerja. Pembangunan ekonomi sangat memerlukan dukungan sumber daya manusia. Pembentukan kualitas sumber daya manusia bertujuan untuk meningkatkan produktivitas pembangunan agar lebih maksimal (Darwanto. 2012: 11).

Perbedaan zaman saat ini dengan zaman dahulu sudah bisa dirasakan oleh banyak kalangan profesi dan bahkan pelajar juga dapat merasakan perkembangan zaman yang sudah terjadi. Perkembangan zaman tidak bisa disaring oleh suatu instansi bahkan negara-pun kesulitan menyaring perkembangan zaman yang akan masuk di suatu negara. Perkembangan zaman dapat ditandai dengan perubahan alat, produksi, dan media yang digantikan oleh sesuatu yang lebih memadai dan efisien.

Salah satu ciri perkembangan zaman yaitu perubahan teknologi yang begitu pesat. Teknologi telah merubah cara berinteraksi dalam komunikasi pemasaran (Lestari. 2015: 412). Teknologi dan informasi yang selalu dengan cepat bertransformasi setiap waktu menimbulkan disrupted. Akibat disrupted (gangguan) membuat beberapa praktisi untuk membuat invasi yang menyesuaikan dengan perkembangan teknologi saat ini.

Dalam bidang perekonomian juga telah terjadi disrupted, banyak pekerjaan yang lama telah tergantikan dengan perkembangan teknologi seperti memanfaatkan aplikasi atau software yang memudahkan pengguna untuk melakukan beberapa aktivitas 
perekonomian. Saat ini kegiatan jual beli dapat dengan mudah terjadi melalui perantara teknologi. Jarak dan waktu menjadi bukan penghalang di zaman saat ini.

Fenomena disrupted membuat banyak kalangan untuk bisa selalu menyesuaikan dengan perubahan teknologi waktu demi waktu. Aktivitas kewirausahaan yang dilakukan berbasis internet marketing membuat kemudahan dalam melakukan bisnis. Hal ini terjadi akibat disrupted sehingga tidak ada lagi yang dapat menghalangi perkembangan teknologi. Beberapa pengaruh perkembangan teknologi juga dialami oleh dunia pendidikan. Saat ini sudah mulai terjadi e-learning atau pembelajaran jarak jauh dengan memanfaatkan teknologi informasi. Instansi pendidikan yang belum bisa menyesuaikan atas fenomena disrupted ini akan 'tergusur' dan digantikan dengan instansi yang mau beradaptasi dengan perkembangan zaman.

Pengguna internet terus berkembang dan hampir 3 miliar orang di seluruh dunia sudah menggunakan internet baik individu maupun perusahaan dengan berbagai tujuan yang hendak dicapai. Jaringan internet yang sering digunakan berasal dari jaringan komputer, telepon seluler telah mempengaruhi secara signifikan sikap dan perilaku konsumen. Menurut Berthon dkk (dalam Valaei, dkk. 2016: 272) menyatakan bahwa internet dapat memberikan target siapapun tidak peduli tempat, dan perbedaan budayanya. Internet yang sudah banyak digunakan oleh banyak orang dari seluruh dunia menandakan bahwa internet sebagai jalur baru untuk berinteraksi sosial tidak memandang lokasi dan budaya dari tiap pengguna internet tersebut.

Ketatnya persaingan dalam dunia kerja harus diimbangi dengan pembelajaran yang di instansi pendidikan dengan pembelajaran yang mampun mempraktekkan langsung bagaimana dalam dunia kerja yang sebenarnya. Memadukan pembelajaran yang telah ada dengan praktek langsung dalam dunia kerja sebenarnya sudah ada sejak dahulu. Di IAIN Syekh Nurjati Cirebon sendiri hal ini telah dilakukan pada beberapa mata kuliah yang ditempuh oleh mahsiswa dan mahasiswinya. Contoh mata kuliah yang menggabungkan pembelajaran dengan praktek langsung dalam dunia kerja adalah mata kuliah entrepreneurship.

Entrepreneurship merupakan salah satu mata kuliah pilihan di jurusan tadris matematika fakultas ilmu tarbiyah dan keguruan di IAIN Syekh Nurjati Cirebon. Fakultas ilmu tarbiyah dan keguruan dalam hal ini menerapkan kurikulum berbasis KKNI, yakni pengembangan dan penyusunan kurikulum yang merujuk pada Learning outcomes (LO) atau captain pembelajaran. Captain pembelajaran pada fakultas ilmu tarbiyah dan keguruan dicapai berdasarkan hasil dari proses pembelajaran melalui pendidikan, pelatihan, dan pengalaman kerja. Hal tersbeut sesuai dengan sistem pendidikan nasional dalam pengembangann kurikulum pendidikan tinggi pada penerapan kurikulum KKNI yang menyatakan bahkan pencapaian pembelajaran dihasilkan berdasarkan internasilisasi dann akumulasi ilmu pengetahuan, pengetahuan, ketetramian, afeksi, dan kompetensi yang dicapai melalui pengalaman kerja (fathoni, 2015)

Entrepreneurship atau yang sering kita kenal dengan kewirausahaan merupakan disiplin ilmu yang menggabungkan antara kecerdasaan berbisnis, inovasi, dan tekan untuk maju. (Vasudha. 2008: 35) Kewirausaahan melihat masalah sebagai peluang untuk membentuk sebuah modal bisnis baru yang bermanfaat bagi pemberdayaan masyarakat sekitar (Karen Braun: 2009).

Sejalan dengan kemajuan jaman, produk perkembangan teknologi seperti alat komunikasi yang selalu dibawa setiap hari harus sejalan dengan pengembangan alur pembelajaran yang berlaku. Pengembangan pembelajaran kewirausahaanatau eduprenuership dapat dilakukan dengan memanfaatkan internet sebagai media sosialisasi dari produk atau jasa yang dihasilkan (marketing). Melalui 
pemanfaatan internet diharapkan dapat meningkatkan keterampilan dan kemampuan internet marketing soft skill dari mahasiswanya.

Mengingat masih terdapat banyak mahasiswa yang kurang begitu peduli dan tidak memiliki kemampuan dalam internet soft skill terutama dalam mata kuliah entrepreneurship. Internet tak hanya memberikan kemudahan tetapi juga menawarkan berbagai media komunikasi yang dapat digunakan untuk pemasaran (Lestari. 2015: 415). Dengan adanya kondisi tersebut maka diperlukan adanya pengembangan bahan ajar materi entrepreneurship berbasis internet marketing soft skill di jenjang perguruan tinggi.

Bahan ajar menjadi salah satu patokan yang dapat menjadikan perserta didik dan mahasiswa menjadi paham dengan yang disampaikan oleh pengajar. Menurut Depdiknas syarat bahan ajar adalah isi bahasa yang sesuai dengan ejaan yang benar, tidak sulit untuk dibaca, dibuat dengan menarik yang dilengkapi dengan ilustrasi untuk menjelaskan makna dan teori yang ada di dalam bahan ajar tersebut. Dengan adanya bahan ajar yang baik dan mudah dipahami maka membantu pembaca atau peserta didik secara cepat mengetahui makna yang sedang dipelajari.

Tujuan penelitian ini adalah untuk menganalisis potensi masalah pembelajaran materi entrepreneurship berbasis internet marketing, untuk proses pengumpulan data dan informasi bahan ajar materi entrepreneurship berbasis marketing, untuk mendisain produk bahan ajar materi entrepreneurship berbasis internet marketing, untuk melakukan validasi dan revisi disain bahan ajar materi entrepreneurship berbasis internet marketing, untuk melakukan uji coba dan revisi produk bahan ajar materi entrepreneurship berbasis internet marketing, dan untuk melakukan uji coba pemakaian dan produksi massal bahan ajar materi entrepreneurship berbasis internet marketing Sedangkan manfaat penelitian ini menghasilkan bahan ajar yang berkualitas dan bermanfaat sehingga dapat membantu mahasiswa dalam mempelajari entrepreneurship.

\section{KAJIAN TEORI}

National Centre for

Competency Based Training (2007)

berpendapat bahwa bahan ajar adalah segala bentuk bahan yang digunakan untuk membantu guru atau instruktur dalam melaksaakan proses pembelajaran. Bahan yang dimaksud dapat beruba bahan tertulis maupun tidak tertulis. Menurut Direktorat Pembinaan sekolah menengah atas (2008:6), bahan ajar adalah segala alat dan media yang berperan sebagai pembantu dalam menjalakan proses pembelajaran. Seperti berupa bahan tertulis maupun bahan tidak tertulis.

Dalam Kamus Besar Bahasa Indonesia (2003: 87) kata "bahan Ajar" berarti segala sesuatu yang dapat dipakai atau dijadikan pedoman atau pengangan untuk mengajar. Dalam website Dimenjur dikemukakan bahwa: Bahan ajar merupakan sekumpulan alat pembelajaran yang berperan dalam pembelajaran yang dibuat secara sistematis sesuai dengan kompetensi dasar sehingga di akhir pembelajaran peserta didik mampu memahami kompetensi secara menyeluruh dan terpadu.

Menurut Depdiknas (2008: 9) secara garis besar manfaat bahan ajar dapat dirasakan oleh guru dansiswa. Manfaat bagi guru yaitu :

a. Diperoleh bahan ajar yan sesuai tuntutan kurikulum dan kebutuhan siswa,

b. Tidak lagi tergantug pada buku teks yang terkadang sulit diperolehm

c. Bahan ajar menjadi lebih beragam dengan berbagai referensi yang sudah dikembangkan,

d. Menambahkan manfaat dan keuntunga atas pengetahuan dan pengalaman guru dalam menulis bahan ajar,

e. Bahan ajar akan mampu menciptakan alur komunikasi pembelajaran yang efektif untuk guru dan siswa, guru lebih dipercayai oleh siswanya, 
f. Diperoleh bahan ajar yang dapat membantu pelaksanaan kegiatan pembelajaran,

g. Dapat diajukan sebagai karya yang dinilai mampu menambah angka kredit untuk keperluan kenaikan pangkat, dan

h. Menambah penghasilan guru jika hasil karya tersebut mampuh diterbitkan dan dibaca oleh banyak pembaca.

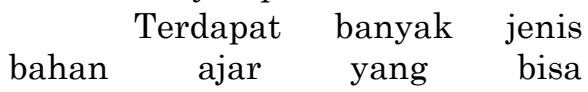
dikembangkan diantaranya adalah handout, buku, modul, buku ajar dan buku teks. Buku ajar adalah salah satu media belajar yang banyak digunakan oleh peserta didik di sekolah, perguruan tinggi sebagai pendamping materi pelajaran dengan isi berupa katakata yang mudah dipahami. Buku teks dibuat oleh pakar bidang tertentu yang dijadikan sebagai standar bahan ajar yang selalu digunakan oleh peserta didik yang di dalamnya berisi tujuan instruksional juga bahasa yang mudah dipahami. Buku teks ini banyak digunakan di kalangan perguruan tinggi sebagai penunjang program studi tertentu. Entreprenurship

merupakan pendidikan pembelajaran tentang usaha dan pemasaran. Entrepreneurship adalah tindakan yang dilakukan secara kreatif dan inovatif dengan menciptakan peluang dan mendapatkan keuntungan dari peluang tersebut sehingga memiliki nilai tambah atau penghasilan tambahan. Di bidang sosial kegiatan Entrepreneurship disebut sosiopreneurship, edupreneurship untuk bidang edukasi, di internal perusahaan interpreneurship, disebut teknopreneurs bisnis teknologi (Ikhwan Alim 2009).

Untuk dapat mencapai tujuan yang diharapkan, maka setiap orang memerlukan ciri-ciri dan juga memiliki sifa dalam kewirausahaan. Ciri-ciri wirausaha antara lain percaya diri, berorientasikan tugas dan hasi, pengambil resiko, kepemimpinan, keorisinilan, berorientasi ke masa depan, jujur dan tekun.

Sedangkan sifat-sifat seorang wirausaha adalah memiliki sifat keyakinan, kemandirian, individualistas, optimisme; selalu berusaha berprestasi, berorientasi pada laba, memiliki ketekunan dan ketabahan, memiliki tekad kuat, suka ebekerja keras, energik, dan meliki sifat inisiatif; memiliki kemampuan mengambil resiko dan suka pada tantangan; bersikap sebagai layaknya pemimpin, mudah bersosialisasi dan menerima dengan baik saran dan kritik dari orang lain; memiliki ide pembaharuan dan kreativitas yang bagus, fleksibel, dapat melakukan apapun dan memiliki jaringan bisnis yang luas; memiliki pandangan hidup dan cara berpikiran jauh ke masa depan; dan memiliki keyakinan bahwa hidup diperlukan kerja keras.

Tujuan marketing menurut Hasan (2013) mencakup maksimalisasi keuntungan, memaksimalkan pangsa pasar, memaksimalkan penjualan, meningkatkan citra merek, meningkatkan kepuasan pelanggan, menyediakan value dan memelihara stabilitas harga.

Pemanfaat website sebagai salah satu wadah pemasaran produk barang dan jasa dapat tidak lepas dari pemanfaatan intrnet secara maksimal. Diharapkan dengan adanya penggunaan internet produk barang atau jasa yang ditawarkan oleh produsen menjadi lebih dapat dikenal luas oleh para konsumen.

Dalam meningkatkan kemampuan internet marketing soft skill terdapat beberapa upaya yang dapat dilakukan, diantaranya sebagai berikut :

- Kemampuan menganalisa

Pengguna atau pelaku bisnis internet harus mampu menganalisa setiap kegiatan ataupun aktifitas marketing yang dilakukan. Para marketer harus mampun menganalisa setiap kebutuhan, keinginan dan 
juga pembelian dari sebuah halaman website yang dimiliki. marketer dapat menentukan dan menetapkan cara apa lagi yang akan dilakukan untuk meningkatkan penjualannya. Marketer juga dapat memberikan prediksi kebutuhan untuk beberapa tahun ke depan.

- Keaktifan di sosial media

Orang memiliki profesi sebagai pembisnis online harus akrab atau aktif dalam menggunakan sosial media. Karena sosial media untuk berkreasi, mencari, mengumpulkan dan menggaet pelanggan lebih banyak dari sosial media.

- Memvisualisasikan data

Dijaman ini, masyarakat lebih menyukai gambar sebagai media untuk menjelaskan sebuah arti. Ini juga yang harus dimiliki oleh seorang digital marketers. marketer harus dapat memvisualisasikan data dalam bentuk gambar, seperti diagram, grafik dan lain sebagainya. Anda bisa menggambarkan ini untuk menjelaskan traffic website. Ketika websitenya terus menunjukkan peningkatan, hal itu dapatditunjukkan kepada pengunjung website.

- Kemampuan teknik

Mempelajari beberapa keterampilan suatu trik bukanlah hal yang merugikan bagi para penjual. Memang terdengar seperti tidak ada gunanya mereka belajar teknik menulis coding secara sederhana, tapi ini dapat membantu mereka dalam produksi video pemasaran.

- Bisa bekerja tim

Perkembangan teknologi mengakibatkan pergeseran cara menjual sebuah produk atau bisnis lainnya, itu sebabnya seorang digital marketers harus mampu bekerja secara tim agar lebah efesien. Di sisi lain juga untuk mendapatkan gagasan atau pendapat yang baru dari anggota tim.

- Mengasah soft skills
Menjadi seorang digital marketers bukan hanya harus mampu memiliki keahlian teknik, menganalisa dan bekerja secara tim. marketer juga harus selalu mengasah soft skills, seperti cara berkomunikasi, cara ramah tamah dan juga cara untuk menjadi fleksibel kepada baik pelanggan maupun rekan kerja. Marketer harus menyeimbangkan antara hard skill dengan soft skill yang digunakan.

Hasil penelitian yang dilakukan oleh F. Puput Martin HB yang berjudul pengembangan bahan ajar science entrepreneurship berbasis hasil penelitian untuk mendukung program kreativitas mahasiswa memberikan kesimpulan bahwa (1) Bahan ajar science entrepreunership yang dikembangkan berbasis hasil penelitian memperoleh penilaian layak dari pakar pakar kewirausahaan, (2). Mahasiswa mampu menyusun proposal Program Kreativitas Mahasiswa (PKM) dengan baik setelah memanfaatkan bahan ajar yang dikembangkan dalam mata kuliah science entrepreunership dan (3). Penggunaan bahan ajar science entrepreunership yang dikembangkan efektif berdasarkan hasil belajar mahasiswa.

\section{METODOLOGI PENELITIAN}

Metode yang digunakan dalam penelitian ini adalah metode "research and development" atau disingkat dengan R\&D. Menurut Sujadi (2003: 164) menyatakan bahwa penelitian dan pengembangan adalah kegiatan yang tersusun untuk menciptakan suatu produk yang baru atau memperbaiki produk serta dapat dipertanggungjawabkan.

Menurut Seels dan Richey (dalam Setyosari, 2010:192) penelitian dan pengembangan ini dalam bentuk yang paling sederhana dapat berupa kajian tentang proses dan dampak rancangan/desain pengembangan dan upaya-upaya pengembangan tertentu, atau berupa suatu situasi dimana seseorang melakukan rencana, pengembangan alat pembelajaran, 
atau langkah evaluasi dan mengkaji proses pada saat yang sama, atau dapat juga berupa kajian tentang rancangan, pengembangan, dan proses evaluasi pembelajaran secara sebagaian proses maupun menyeluruh.

Terdapat beberapa langkah dalam penelitian dan pengembangan (reseacr and develompment) yang telah dikemukakakn oleh Brog \& Gall (1979) dan Mc. Millan, J.H dan Schumacher dalam Yani Ramdani(2012: 46-47), antera lain : (1) meneliti dan mengumpulkan informasi, membaca literature, melakukan observasi dan menyiapkan laporan kebutuhan pengembangan; (2) merencanakan prototype komponen yang akan dikembangkan, mendefinisikan, merumusan tujuan, menentukan urutan kegiatan dan membuat skala pengukuran; (3) Mengembangkan prototype awal, buku sumber, bahan pelajaran dan alat evaluasi; (4) melakukan uji coba terbatas terhadap model awal, melalukan pengamata, wawancara dan angket. Hasil dianalisis untuk menyempurnakan model awal; (5) merevisi model awal berdasarkan hasil ujuu coba dan analisis data; (6) melakukan uji coba lapangan pada model awal; (7) melakukan revsisi produk berdasarkan hasil uji coba lapangan dan hasil analisisnya; (8) melakukan uji coba lapangan secara operasional lebih luas, mengumpulkan data, dan dianalisis; (9) melakukan perubahan akhir terhadap model lapangan sehingga menjadi model akhir; dan (10) melakukan diseminasi dan penyebaran kepada berbagai pihak penelitian untuk digunakan.

Prosedur penelitian pengembangan menurut Sugiyono memiliki langkah-langkah seperti bagan berikut ini

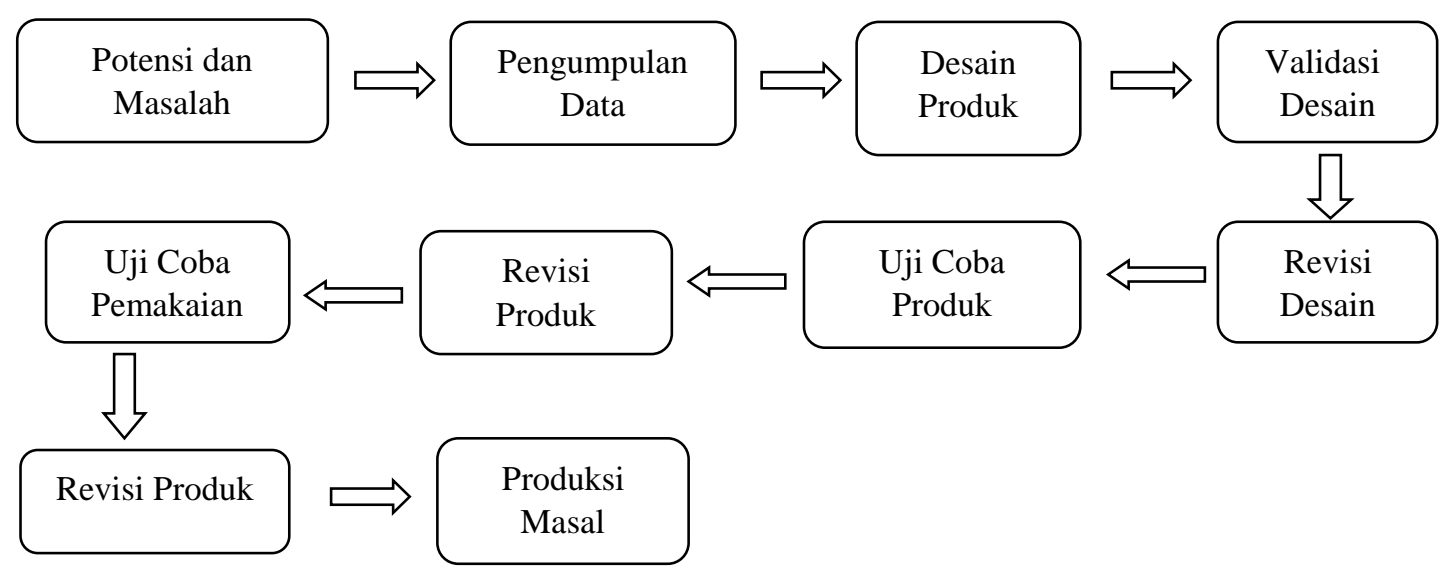

Pada penelitian dan pengembangan bahan ajar entrepreneurship berbasis internet marketing mahasiswa di IAIN Syekh Nurjati Cirebon mengunakan Sumber data yang didapatkan melalui pengujian baik hasil uji coba terbatas maupun uji keluasan dari hasil produk pegembangan materi entrepreneurship tersebut. Selain itu untuk mengukur efetifitas dan efisiensi dalam penelitian ini yakni dengan penggunaan wawancara, lembar obsrvasi, dan angket terhadap sikap (respon) penerapan edupreuner program.

1. Wawancara

Wawancara dilakukan untuk mengetahui tanggapan, komentar, dan saran mahasiswa setelah mengikuti kegiatan edupreuneur program. Metode wawancara dipilih karena peneliti dapat lebih dekat dengannarasumber sehingga informasi yang diperoleh lebih mendalam. Wawancara dilakukan terhadap mahasiswa jurusan tadris matematika yang mengikuti kelas entrepreneurship.

2. Lembar Observasi 
Observasi dilakukan untuk mengetahui respon mahasiswa saat mengikuti kegiatan edupreneur program. Observasi dilakukan oleh peneliti yang juga berperan sebagai observer saat pelaksanaan kegiatan entrepreneurship.

3. Angket(Kuesioner)

Angket (Kuesioner) digunakan untuk mengetahui penilaian ahli materi dan ahli media (internet) mengenai Pengembangan bahan ajar materi entrepreneurship berbasis Internet Marketing Soft Skill Mahasiswa. Kuesioner yang digunakan dalam penelitian dan pengembangan ini adalah kuesinoer berstruktur dengan menggunakan skala Likert. Alternatif jawaban menurut skala Likert yaitu; Sangat Setuju (SS), Kurang Setuju (KS), Setuju (S), Tidak Setuju (TS) (Sukardi, 2009:146).

Tabel 1

Skor Kuesioneruntuk Pernyataan Positif dan Negatif

\begin{tabular}{|l|l|l|l|}
\hline \multirow{2}{*}{ No } & \multirow{2}{*}{ Keterangan } & Skor \\
\cline { 3 - 4 } & & Positif & Negatif \\
\hline 1 & Sangat setuju & 4 & 4 \\
\hline 2 & Kurang Setuju & 3 & 3 \\
\hline 3 & Setuju & 2 & 2 \\
\hline 4 & Tidak setuju & 1 & 1 \\
\hline
\end{tabular}

Sumber : (Sugiyono, 2011)

Data proses pengembangan produk media internet pada kegiatan edupreneur program berupa data deskriptif, yaitu tinjauan dan saran dari ahli media sesuai dengan prosedur pengembangan yang dilakukan. Media ini divalidasi oleh ahli materi dan ahli media. Setelah divalidasi oleh ahli materi dan ahli media, media kemudian direvisi sehingga diperoleh media revisi tahap I. Media hasil revisi tahapi kemudian diujicobakan dengan cara digunakan oleh peneliti pada kegiatan edupreneur program.Media yang telah melalui proses ujicoba akan direvisi kembali.

1. Data kelayakan produk yang dihasilkan

Data kelayakan produk yang dihasilkan, ditentukan melalui analisis hasil validasi ahli materi, ahli media, dan ujicoba penggunaan oleh guru serta siswa.Data hasil validasi ahli materi dan ahli media dianalisis secara deskriptif. Langkah-langkahnya adalah sebagai berikut:

a. Mengubah penilaian dalam bentuk kualitatif menjadi kuantitatif

b. Setelah data terkumpul, lalu menghitung skor rata-rata

c. Mengubah skor rata-rata menjadi nilai kualitatif dengan kriteria

HASIL

\section{PENGEMBANGAN}

PENELITIAN

Pengembangan bahan ajar yang dilaksanakan dalam penelitian ini melalui beberapa tahapan pengembangan sesuai teori yang dikembangkan oleh Reiser dan Mollenda, yaitu model pengembangan ADDIE yang meliputi tahapan Analysisi, Design, Development, Impelemntation and Evaluation. Hasil penelitian yang menggunkan kelima tahapan tersebut dapat dilihat sebagai berikut.

Analisis

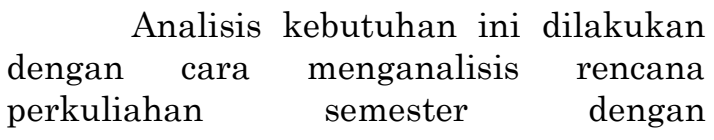

dipadukannya bersamaan dengan analisis kebutuhan lapangan atau akademis. Analasis kebutuhan akademis merupakan suatu kompetensi yang harus dicapai oleh mahasiswa dengan kurikulum yang sedang berlaku pada saat semester dimana mahasiswa melakukan perkuliahaan mata kuliah entrepreneurship.

Desain

Kegiatan yang kedua dalam penelitian pengembangan bahan ajar entrepreneurship yaitu membuat desain melalui storyboard. Storyboard merupakan kumpulan tulisan atau catatan penting dari bahan ajar yang hendak dikembangkan. Dengan kata lain, tahap ini diperoleh data 
dan informasi penting untuk menunjang pengembangan bahan ajar rentrepreneurship serta bahan-bahan yang dibutuhkan sesuai dengan teks, materi, gambar dan juga ilustrasi.

Development

Kegiatan ketiga dalam penelitian pengembangan bahan ajar entrepreneurship adalah membangun dari desain yang sudah diciptakan pada tahapan sebelumnya. Pengembangan bahan ajar dilakukan sesuai dengan desain yang sudah ada atau hasil dari tahap kedua dalam penelitian pengembangan ini. Bahan ajar yang selesai dikembangan sesuai kebutuhan akademis selanjutnya dilakukan penilaian terhadap isi, dan tampilan serta keterbacaan narasi yang ada di bahan ajar entrepereneurship. Penilaian terhadap suatu hasil bahan ajar yang dikembangkan dilakukan oleh ahli media dan ahli materi.

Implementation

Tahap implementation ini merupakan suatu kegiatan yang dilakukan peneliti menerapkan hasil produk bahan ajar entrpeneurship di kelas eksperimen yang sudah ditetapkan.

Proses implementasi dilakukan bertujuan untuk menguji coba produk bahan ajar entreperenurship oleh beberapa mahasiswa yang dijadikan sebagai sampel eksperimen produk. Uji coba produk bahan ajar ini adalah proses penyediaan dan mengumpulkan informasi untuk dijadikan sebagai dasar pengambilan keputusan dalam rangka meningkatkan kualitas bahan ajar entrepeneurship atau produk yang sedang dikembangkan dalam suatu penelitian.

Evaluation

Evaluasi bertujuan untuk mengetahui apakah produk yang dikembangkan sesuai dengan tujuan yang diharapkan. Data dan informasi yang jadikan sebagai bahan evaluasi diantaranya adalah nilai pretes mahasiswa, hasil validasi produk yang dilakukan oleh dua orang validator, hasil uji coba produk terbatas, dan nilai postes mahasiswa serta juga angket respon mahasiswa terhadap bahan ajar entrepeneurship yang sedang dikembangkan. Tahap evaluasi dan pengembangan penelitian terdiri dari 2 jenis evaluasi, diantaranya yaitu evaluasi formatif 1 dan formatif 2 .
Respon mahasiswa terhadap bahan ajar entrepreneurship berbasis internet marketing diperoleh melalui penyebaran angket kepada sampel penelitian yaitu mahasiswa yang sedang menempuh mata kuliah entrepeneurship. Angket dibentuk dengan 3 aspek yang berjumlah 20 item pernyataan. Tujuan penyebaran angket ini adalah untuk mengetahui karakteristik bahan ajar entrereneurship berbasis internet marketing yang sedang dikembangkan.

Tabel 3

Deskripsi Angket Bahan Ajar

\begin{tabular}{|l|r|r|}
\hline & Angket & \multicolumn{1}{|c|}{$\begin{array}{l}\text { Valid N } \\
\text { (listwise) }\end{array}$} \\
\hline Marketing & 20 & 20 \\
Minimum & 27 & \\
Maximum & 51 & \\
Mean & 78 & \\
Std. & 66,00 & \\
Deviation & 5,181 & \\
Variance & 26,842 & \\
\hline
\end{tabular}

Dari hasil perolehan penyebaran angket respon mahasiswa terhadap bahan ajar entrepreneurship berbasis internet marketing diketahui bahwa nilai rata-rata respon mahasiswa sebesar 66, standar deviasi sebesar 5,181, varian sebesar 26,842 , nilai minimum sebesar 51 , nilai maksimum 78 dan marketing sebesar 27. Untuk mengetahui perolehan respon mahasiswa berdasarkan aspek angket dap dilihat melalui tabel berikut:

Tabel 4

Presentase Aspek Angket

\begin{tabular}{|c|c|}
\hline Aspek & Presentase \\
\hline Aspek Kualitas Isi & $66 \%$ \\
\hline $\begin{array}{ll}\text { Aspek } & \text { Kualitas } \\
\text { Teknis } & \end{array}$ & $67 \%$ \\
\hline $\begin{array}{l}\text { Aspek Kualitas } \\
\text { Pembelajaran }\end{array}$ & $66 \%$ \\
\hline
\end{tabular}

Angket respon yang disebarkan kepada responden terdiri dari tiga aspek yaitu aspek kualitas isi, kualitas teknis, dan kualitas pembelajaran. Hasil angket respon berdasarkan aspek angket yaitu aspek kualitas isi memperoleh persentase sebesar 66\%, aspek kualitas teknis memperoleh persentase sebesar $67 \%$ dan aspek kualitas pembelajaran memiliki persentase 66\%. Dari ketiga persentase aspek tersebut dapat diketahui bahwa 
aspek kualitas teknis memiliki persentase tertinggi diantara ketiga aspek lainnya. Dengan kata lain aspek kualitas teknis tergolong dapat kategori cukup baik.

Tes dilakukan untuk mengetahui efektivitas penggunaan bahan ajar entrepreneurship berbasis internet arketing. Tes disebarkan sebanyak dua kali yaitu pretes dan postes. Hasil perhitungan pretes adalah sebagai berikut:

Tabel 5

Deskripsi Hasil Pretes

Descriptive Statistics

\begin{tabular}{|l|r|r|}
\hline & pretes & \multicolumn{1}{|c|}{$\begin{array}{c}\text { Valid N } \\
\text { (listwise) }\end{array}$} \\
\hline $\mathrm{N}$ & 20 & \\
Marketing & 30 & \\
Minimum & 40 & \\
Maximum & 70 & \\
Mean & 58,55 & \\
Std. & 8,127 & \\
Deviation & 66,050 & \\
Variance & \\
\hline
\end{tabular}

Berdasarkan tabel 5 mengenai deskripsi hasil pretes yang berasal dari sampel sebanyak 20 mahasiswa didapatkan nilai rata-rata sebesar 59,55, nilai maksimum sebesar 70 , nilai minimum sebesar 40, marketing sebesar 30, standar deviasi atau simpangan baku sebesar 8,127 dan varians sebesar 66,050. Sedangkan hasil perhitungan deskripsi postes dapat dilihat melalui tabel di bawah ini.

Tabel 6

Deskripsi Data Postes

Descriptive Statistics

\begin{tabular}{|l|r|r|}
\hline & postes & \multicolumn{1}{|c|}{$\begin{array}{c}\text { Valid N } \\
\text { (listwise) }\end{array}$} \\
\hline $\mathrm{N}$ & 20 & 20 \\
Marketing & 16 & \\
Minimum & 75 & \\
Maximum & 91 & \\
Mean & 83,55 & \\
Std. & 4,850 & \\
Deviation & 23,524 & \\
Variance & \\
\hline
\end{tabular}

Berdasarkan tabel 6 mengenai deskripsi hasil postes yang berasal dari sampel sebanyak 20 mahasiswa didapatkan nilai rata-rata sebesar 83,55 , nilai maksimum sebesar 91, nilai minimum sebesar 75 , marketing sebesar 16 , standar deviasi atau simpangan baku sebesar 4,850 dan varins sebesar 23,524.

Hasil perbedaan pretes dan postes dapat dilihat melalui diagram di bawah ini.

Diagram 1

Perbedaan Nilai Pretes dan

\section{Diagram Pretes dan Postes}

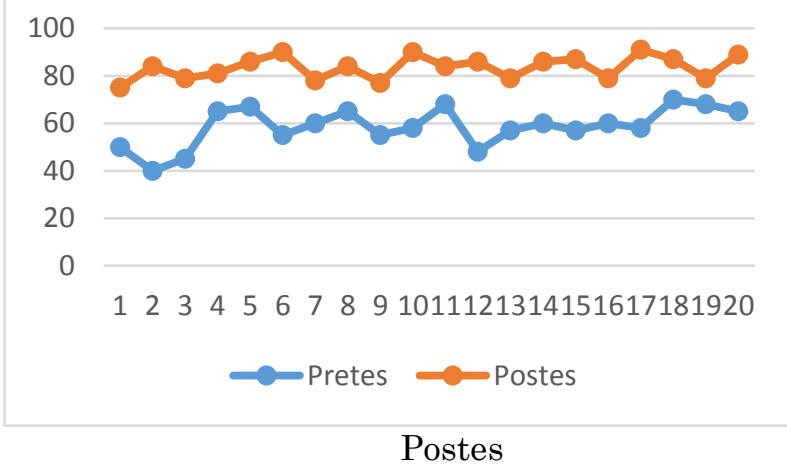

Berdasarkan diagram di atas dapat diketahui bahwa penyebaran nilai postes lebih tinggi daripada penyebaran nilai pretes. Sehingga dapat dikatakan terjadinya perubahan nilai setelah diadakannya postes dan setelah pembelajaran menggunakan bahan ajar entrepreneurship berbasis internet marketing. Terihat juga bahwa nilai minimum dan maksimum pretes dan postes berbeda, sehingga demikian nilai minimum postes lebih baik daripada nilai pretes dimana sebelum diadakannya pembelajaran menggunakan bahan ajar yang sedang dikembangkan dalam penelitian ini.

Untuk mengetahui adakan efektivitas bahan ajar entrepreneurship berbasis internet marketing maka dilakukan uji efektivitas menggunakan uji paired sampel t-test. Data yang digunakan dalam pengujian merupakan hasil tes sebelum dan sesudah pembelajaran menggunakan bahan ajar entrepreneurship berbasis internet marketing. Perhitungan uji paired sampel t-test ini berbantuan software SPSS. Berdasarkan hasil perhitungan menggunakan SPSS maka dihasilkan output seperti di bawah ini.

Tabel 7

Uji Paired Sample t-test

Paired Samples Test 


\begin{tabular}{|lll|r|}
\hline & & \multicolumn{1}{|c|}{ Pair 1 } \\
\cline { 3 - 3 } & & \multicolumn{1}{c|}{$\begin{array}{c}\text { Pretes - } \\
\text { Postes }\end{array}$} \\
\hline & Mean & $-25,000$ \\
Paired & Std. Deviation & 8,730 \\
Differences & Std. Error Mean & & 1,952 \\
& 95\% Confidence Interval & Lower & $-29,086$ \\
$\mathrm{~T}$ & of the Difference & Upper & $-20,914$ \\
Df & & & $-12,807$ \\
Sig. (2-tailed) & & 19 \\
\hline
\end{tabular}

Uji paired sampel t-test akan memberikan jawaban yang positif jika dan hanya jika angka signifikansi kurang dari 0,05. Berdasarkan uji efektivitas produk menggunakan uji paired sampel t-test diketahui bahwa angka signifikansi sebesar 0,000 artinya bahwa signifikansi kurang dari 0,05. Sehingga dapat disimpulkan bahwa daya efektivitas pembelajaran setelah menggunakan bahan ajar entrepreneurship berbasis internet marketing.

\section{PEMBAHASAN}

Bahan ajar entrepreneurship berbasis internet marketing menggunakan teori metode pengembangan penelitian sehingga produk bahan ajar memiliki karakteristik yang sudah divalidasi dan dievaluasi oleh ahli / expert judgment. Berdasarkan hasil validasi yang sudah dilakukan yaitu validasi oleh ahli media dan validasi oleh ahli materi. Dari segi kualitas isi memperoleh rata-rata sebesar $66 \%$ termasuk dalam kategori baik. Dari segi kualitas teknis bahan ajar entrepreneurship berbasis internet marketing memperoleh rata-rata $66 \%$ termasuk dalam kategori baik. Dan dari segi respon bahan ajar entrepreneurship berbasis internet marketing memperoleh rata-rata $77 \%$ termasuk kategori baik. Di samping itu, validator selain memberikan respon terhadap bahan ajar yang dikembangkan, namun juga validator memberikan saran dan masukan untuk bahan ajar entrepreneurship berbasis internet marketing agar lebih baik dan meminimalisir dari kelemahan yang ada di lapangan.

$$
\text { Bahan ajar entrepreneurship }
$$

berbasis internet marketing telah diuji cobakan lapangan secara terbatas yaitu kepada mahasiswa yang mengambil mata kuliah entrepreneurship. Berdasarkan uji coba terbatas diketahui beberapa kelemahan dan kelebihan sehingga perlu diadakannya perbaikan bahan ajar entrepreneurship berbasis internet marketing. Setelah tahap revisi atau perbaikan dari uji coba terbatas yang pertama, kemudian dilakukan uji coba terbatas yang keduk kali dan memperoleh hasil respon yang cukup baik. Setelah dirasa cukup maka bahan ajar entrepreneurship berbasis internet marketing yang sedang dikembangkan memiliki karakteristik yang disesuaikan berdasarkan sampel penelitian.

Penelitian pengembangan bahan ajar entrepreneurship berbasis internet menggunakan sampel sebanyak 20 mahasiswa yang akan menggunakan produk pengembangan bahan ajar berbentuk buku perkuliahan mata kuliah entrepreneurship. Dari sampel 20 mahasiswa ini dilakukan dua kali tes bertujuan untuk mengetahui adakah perbedaan antara sebelum dan sesudah penggunaan produk pengembangan bahan ajar dan juga untuk mengetahui berapa efektif bahan ajar yang sedang dikembangkan dalam penelitian ini yaitu berbentuk buku atau modul perkuliahan entrepreneurship.

Dari hasil penyebaran pretes diketahui bahwa nilai terendah yang diperoleh oleh salah satu mahasiswa adalah 40 dan nilai tertingginya adalah 70 sehingga dapat diketahui marketing atau selisihnya adalah 30. Dengan kata lain diperoleh rata-ratanya adalah antara nilai minimum dan maksimum yaitu 58,55. Dilihat dari nilai rata-rata pretes mahasiswa dapat diprediksi bahwa mahasiswa masih kurang memahami materi mengenai entrepreneurship. Nilai rata-rata 58,55 masih dianggap kecil dari secara persentase belum mencapai $75 \%$ 
sehingga perlu adanya upaya atau usaha yang dapat meningkatkan pemahaman entrepreneurship mahasiswa.

Diketahui pula varian dari nilai pretes 20 mahasiswa sebesar 66,050. Dari nilai varian ini dapat dikatakan jawaban seluruh sampel penelitian tidaknya banyak yang memiliki kesamaan jawaban, yang artinya bahwa mahasiswa dapat menyelesaikan pretes secara mandiri atau tidak tergantung pada jawaban dari mahasiswa yang lainnya. Sedangkan standar deviasi atau simpangan baku dari nilai pretes diketahui bahwa 8,127. Dari angka standar deviasi ini dapat diketahui bahwa semakin mendekati nol maka nilai rata-rata yang diperoleh semakin merepresentasikan keadaan mahasiswa atau subjek penelitian. Dengan kata lain, mahasiswa mengerjakan soal pretes sesuai dengan kemampuannya dan tidak memberikan jawaban yang acak.

Dari keadaan nilai pretes yang ada di kelas penelitian ini, maka peneliti melakukan sedikit observasi mengenai bahan ajar yang seperti apa untuk membantu proses pembelajaran entrepreneurship yang akan mereka pelajar. Oleh sebab itu, informasi yang diperoleh dari hasil observasi ini akan dijadikan sebagai data peneliti untuk mengembangkan produk bahan ajar yang diinginkan.

Dari hasil penyebaran postes diketahui bahwa nilai terendah yang diperoleh oleh salah satu mahasiswa adalah 75 dan nilai tertingginya adalah 91 sehingga dapat diketahui marketing atau selisihnya adalah 16. Dengan kata lain diperoleh rata-ratanya adalah antara nilai minimum dan maksimum yaitu 83,524. Dilihat dari nilai rata-rata postes mahasiswa dapat diprediksi bahwa mahasiswa masih sudah mampu memahami materi mengenai entrepreneurship. Nilai rata-rata 83,524 dimana dianggap melebihi secara persentase mencapai $75 \%$ sehingga mahasiswa telah mampu memahami materi entrepreneurship setelah merakan pembelajaran menggunakan bahan ajar yang dikembangkan.

Diketahui pula varian dari nilai postes 20 mahasiswa sebesar 23,524. Dari nilai varian ini dapat dikataka jawaban seluruh sampel penelitian tidaknya banyak yang memiliki kesamaan jawaban, yang artinya bahwa mahasiswa dapat menyelesaikan pretes secara mandiri atau tidak tergantung pada jawaban dari mahasiswa yang lainnya. Sedangkan standar deviasi atau simpangan baku dari nilai pretes diketahui bahwa 4,850. Dari angka standar deviasi ini dapat diketahui bahwa semakin mendekati nol maka nilai rata-rata yang diperoleh semakin merepresetasikan keadaan mahasiswa atau subjek penelitian. Dengan kata lain, mahasiswa mengerjakan soal postes sudah sesuai dengan kemampuannya dan tidak memberikan jawaban yang acak.

Dari hasil pengolahan dan perhitungan data angket diketahui bahwa rata-rata respon siswa adalah 66 dengan skor maksimum adalah 78 dan skor minimum adalah 51. Dari hasil skor ratarata respon mahasiswa terhadap bahan ajar entrepreneurship berbasis internet marketing dapat diprediksikan bahwa mahasiswa masih kurang menyatakan kegembiraan belajar menggunakan bahan ajar entrepreneurship berbasis internet marketing. Diketahui pula frekuensi perolehan skor respon mahasiswa yang kurang dari 70 sebanyak 16 mahasiswa dan respon mahasiswa yang lebih dari 70 sebanyak 4 mahasiswa. Dengan kata lain skor rata-rata 66 menyatakan mahasiswa tidak memberikan respon yang baik dari segi ketiga aspek dalam mengembangkan bahan ajar entrepreneurship berbasis internet marketing.

Dari hasil perhitungan angket diketahui pula standar deviasi atau simpangan baku sebesar 5,181 dan varian sesar 26,842. Dari hasil perhitungan standar deviasi sebesar 5,181 yang artinya mendekati nol maka dapat diartikan bahwa skor respon mahasiswa tidak menjauhi dari rata-ratanya. Hal ini terlihat dari skor minimum respon adalah 51 dan skor maksimum sebesar 78 , sedangkan skor rata-ratanya adalah 66 . Hasil perhitungan varian sebesar 26,842 yang artinya semakin menjauhi angka nol dapat diartikan bahwa sampel atau mahasiswa sebagai subjek penelitian memberikan jawaban respon yang sangat beragam berdasarkan perasaan dan penilaian terhadap bahan ajar entrepreneurship berbasis internet marketing.

Hasil skor rata-rata angket respon mahasiswa sebesar 66 masih jauh dari kesimpulan yang baik atau bahan ajar memiliki nilai yang baik sebagai pendamping perkuliahan entrepreneurship. 
Oleh karena itu, perlu diadakannya beberapa perbaikan yang dianggap perlu. Untuk mengetahui beberapa kekurangan yang ada dalam bahan ajar entrepreneurship berbasis internet marketing, peneliti telah menghitung hasil respon siswa berdasarkan tiga aspek respon terhadap bahan ajar entrepreneurship berbasis internet marketing.

Pada aspek 1 dengan 5 item pernyataan yang diisi oleh 20 mahasiswa diperoleh persentase rata-rata sebesar $66 \%$ dan untuk responden yang memberikan respon sangat setuju dan setuju adalah $41 \%$, untuk responden yang memberikan respon ragu-ragu sebesar $57 \%$ dan untuk respon tidak setuju dan sangat tidak setuju sebesar 1\%. Pada aspek 2 dengan jumlah 7 item pernyataan diperoleh persentase ratarata sebesar 66\%. Responden yang memberikan respon sangat setuju dan setuju sebesar $42 \%$, untuk responden yang memberikan respon ragu-ragu sebesar 55\% dan untuk respon tidak setuju dan sangat tidak setuju sebesar 3\%. Pada aspek 3 dengan jumlah 8 item pernyataan diperoleh persentase rata-rata sebesar $67 \%$. Responden yang memberikan respon sangat setuju dan setuju sebesar $41 \%$, untuk responden yang memberikan respon ragu-ragu sebesar 58\% dan untuk respon tidak setuju dan sangat tidak setuju sebesar $1 \%$.

\section{SIMPULAN}

Berdasarkan hasil penelitian dan analisis data pada BAB IV tentang Pengembangan Bahan Ajar Entrepeneurship berbasis Internet Marketing dapat disimpulkan sebagai berikut.

1. Penelitian pengembangan ini menghasilkan bahan ajar entrepreneurship berbasis internet marketing sebagai bahan ajar entrepreneurship sebagai pendamping perkuliahan mahasiswa tadris mahasiswa matematika tahun ajaran 2017-2018 dengan menggunakan langkah-langkah penelitian pengembangan berpendekatan ADDIE. Penelitian ini dilaksanakan hanya terbatas sampai uji coba terbatas dan tidak hingga produksi asal dikarenakan keterbatasan waktu penelitian.

2. Kualitas bahan ajar entrepreneurship berbasis internet marketing yang berhasil dikembangkan berdasarkan hasil validasi dua orang ahli materi dan ahli media termasuk dalam kategori cukup. Hasil tes sebelum dan sesudah mengiakan bahan ajar entrepreneurship berbasis internet marketing mengalami kenaikan . Respon mahasiswa tadris matematika terhadap bahan ajar entrepreneurship berbasis internet marketing adalah baik.

3. Berdasarkan perolehan data penelitian yang berasal dari nilai pretes, postes dan angkat memiliki kriteria berdistribusi normal dan homogen. Sedangkan uji efektivitas bahan ajar entrepreneurship berbasis internet marketing menggunakan uji paired sampel $t$-test. Hasil perhitungan menggunakan SPSS menghasilkan output signifikansi 0,000 yang artinya kurang dari 0,05 sehingga dapat disimpulkan bahwa bahan ajar entrepreneurship berbasis internet marketing efektif terhadap hasil belajar mahasiswa pada mata kuliah entrepreneurship.

\section{SARAN}

Waktu untuk pelaksanaan penelitian hendaknya memiliki jangka waktu yang lebih lama agar dapat mengobservasi lebih mendalam terhadap kelebihan dan kekurangan produk yang sedang dikembangkan. Bahan ajar entrepreneurship dapat dikembangkan melalui pendekatan lainnya yang lebih kontekstual dan sesuai kebutuhan mahasiswa serta untuk dapat meningkatkan keterampilan demi menunjang kehidupan mereka.

\section{DAFTAR PUSTAKA}

Chaturvedi, A., Yadav, A., \& Bajpai, S. (2011). Communicative approach to soft and Hard skills. Journal VSRD-International of bussiness \& management research Vol 1 (1).

Darwanto. 2012. Peran Entrepreneurship Dalam Mendorong Pertumbuhan Ekonomi dan Peningkatan Kesejahteraan Masyarakat. Diseminasi Riset Terapan Bidang Manajemen \& Bisnis Tingkat Nasional Jurusan Administrasi Bisis Politeknik Negeri Semarang Universitas Diponegoro 
Departemen Pendidikan Nasional. 2008.

Pengembangan Bahan Ajar dan

Media. Jakarta: Departemen

Pendidikan Nasional

F. Puput Martin HB. 2012. Pengembangan

Bahan Ajar Science

Entrepreneurship Berbasis Hasil

Penelitian untuk Mendukung

Program Kreativitas Mahasiswa.

Jurnal Penelitian Pendidikan Vol 29 No 2

Fathoni, A. (2015). Manajemen

Pengembangan Kurikulum

Berbasis KKNI. Al idarah jurnal manajemen pendidikan, 5(1), 76-

91.

Gliem, R. R., \& Gliem, J. A. (2003). Calculating, interpreting, and reporting Cronbach's alpha reliability coefficient for Likerttype scales. Midwest Research-toPractice Conference in Adult, Continuing, and Community EducationEbel,195.

Hasan, A. (2013). Marketing Dan KasusKasus Pilihan. Yogyakarta: Caps

Ikhwan, A. (2010). Peranan ITB dalam Pengembangan Kewirausahaan. Menteri Koordinator Pengembangan Kemahasiswaan Kabinet KM ITB 2009-2010. Diperoleh dari http://ikhwanalim. wordpress.com

Inmon, W. H., O'Neil, B., \& Fryman, L. (2010). Business metadata: capturing enterprise knowledge. Morgan Kaufmann.

Jones, K. O., \& Kelley, C. A. (2003). Teaching marketing via the Internet: Lessons learned and challenges to be met. Marketing Education Review, 13(1), 81-89

Karen Braun, Social Entrepreneurship: Perspectives on an Academic Discipline. Theory in Action, Vol. 2, No. 2, April 2009.

Kotler, P.\& Keller, K. L.. 2009. Manajemen Pemasaran. Jilid 1. Edisi ke 13. Diterjemahkan oleh: Bob Sabran. Jakarta: Erlangga.
Lawshe, C. H. (1975). A quantitative approach to content validity1. Personnel psychology, 28(4), 563-575.

Lestari, Desti Putri. 2015. Analisis strategi internet marketing butik online di Surabaya melalui instagram. Commonline Departemen Komunikasi Vol. 4 No. 2

Lestari, Ika. 2013. Pengembangan Bahan Ajar Berbasis Kompetensi. Padang: Akademia.

Leung, L. (2008). How teached can broaden their soft skills. New York: IT Career and Training Alert newsletter.

Mitchell, G. W. (2008). Essential soft skills for success in the twenty-first century workforce as perceived by Alabama business/marketing educators. Proquest.

Sugiyono, D. (2010). Metode penelitian kuantitatif kualitatif dan R\&D. Penerbit Alfabeta.

Sujadi, 2003. Metodologi Penelitian Pendidikan. Jakara. Rineka Cipta.

Swastha, B. (1990). Manajemen pemasaran modern. Yogyakarta: Liberty.

Valaei, Naser., dkk. 2016. The Effect of Culture on Attitude Towards Online Advertising And Online Brands: Applying Hofstede's Cultural Factors To Internet Marketing. Journal of Internet Marketing And Advertising Vol. 10. No. 4

Vasudha Vasakaria. A Study on Social Entrepreneurship and the Characteristics of Social Entrepreneur, The Icfaian Journal of Management Research, Vol. VII, No. 4, 2008.

Yates, L. (2005). Fact sheet generic skills. AMEP Research centre. Retrieved from http://www.ameprc.mq.edu.au/docs/ fact_sheets/04TeachingIssuesforWe $\underline{\text { bpdf }}$ 